\title{
Hiatal hernia after esophagectomy - a report of two cases
}

\author{
Bogumił Maciąg, Janusz Wójcik, Jarosław Pieróg, Norbert Wójcik, Karina Witkiewicz, Tomasz Grodzki
}

Department of General Thoracic Surgery and Transplantation, Pomeranian Medical University, Szczecin, Poland

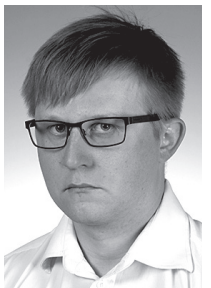

Kardiochirurgia i Torakochirurgia Polska 2017; 14 (1): 50-51

\begin{abstract}
Postoperative hiatal hernia after esophagectomy occurs with a frequency of $0.4-6 \%$, and the local conditions following esophagectomy promote its occurrence. In the material presented here, hiatal hernia in the form of displacement of the colon to the mediastinum was established in $0.78 \%(2 / 256)$ of all performed esophagectomies. Both cases were reoperated successfully.
\end{abstract}

Key words: esophagectomy, hiatal hernia, colon displacement.

\section{Introduction}

Complications after esophagectomy occur in up to $40 \%$ of cases [1, 2]. Pneumonia, respiratory failure, and anastomotic leaks are the most common early complications in the first postoperative week. The most common late complication, usually developing after several weeks or months, is anastomotic stenosis [1-3]. Hiatal hernia after esophagectomy occurs in both the early and late postoperative period with a frequency of $0.4-6 \%$ [1-5]. This complication was found in $2(0.78 \%)$ cases in our material.

\section{Case reports}

\section{Case 1}

A 34-year-old woman was admitted with squamous cell cancer of the cervical esophagus. She underwent total hybrid McKeown resection of the esophagus (VATS with

\section{Streszczenie}

Pooperacyjna przepuklina rozworu przełykowego po resekcji przełyku występuje z częstością 0,4-6\%, a warunki ezofagektomii sprzyjają jej powstaniu. W materiale autorów przepuklina rozworu w postaci przemieszczenia okrężnicy do śródpiersia powstała w 0,78\% (2/256) ogółu wykonanych resekcji przełyku. Oba przypadki operowano ponownie z powodzeniem.

Słowa kluczowe: resekcja przełyku, przepuklina rozworu, przemieszczenie okrężnicy.

laparotomy and cervicotomy) with pharyngogastric anastomosis as well as microjejunostomy, pyloromyoplasty, the Kocher maneuver, and three-field lymphadenectomy. Stage IA (pT1aNOMo) was confirmed by postoperative specimen examination. Tachycardia (100/min) was observed between the $4^{\text {th }}$ and $7^{\text {th }}$ postoperative day. Oral contrast X-ray examination revealed stenosis of the pylorus at the level of the hiatus (Figs. 1 A-D). The pylorus was compressed by the malpositioned colon. A decision was made to perform a reoperation, which included colon repositioning, hiatal plasty, and right hemicolectomy due to ischemia and necrosis. The postoperative period was complicated by peritonitis, which was successfully treated with peritoneal lavage.

\section{Case 2}

The 32-year-old patient was admitted to our department with a diagnosis of adenocarcinoma between the

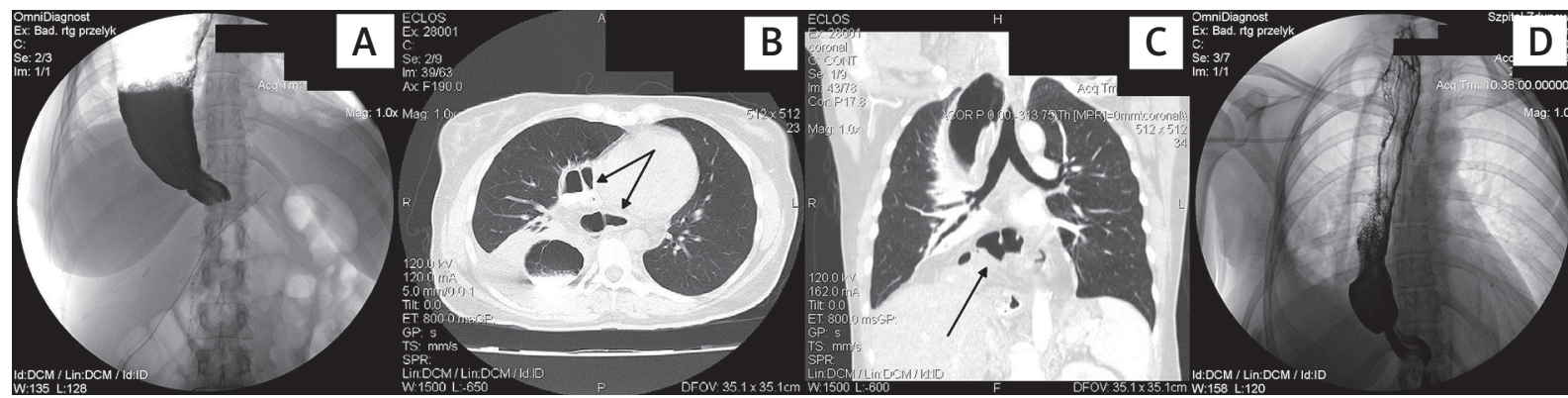

Fig. 1. A - Oral X-ray examination with contrast performed on the $7^{\text {th }}$ postoperative day after esophagectomy. Graft stenosis visible at the hiatus level. B - Horizontal computed tomography (CT) image: the colon protruding into the mediastinum. C - Coronal CT image: the colon protruding into the mediastinum. D - Final oral X-ray examination with contrast: restoration of stomach graft patency

Address for correspondence: Janusz Wójcik MD, PhD, Assoc. Prof., Department of General Thoracic Surgery and Transplantation, Pomeranian Medical University, 11 Sokołowskiego St, 70-891 Szczecin, Poland, phone: +48 509501 716, fax: +48 91 4620 836, e-mail: janusz.zenon.wojcik@wp.pl Received: 26.05.2016, accepted: 18.08.2016. 


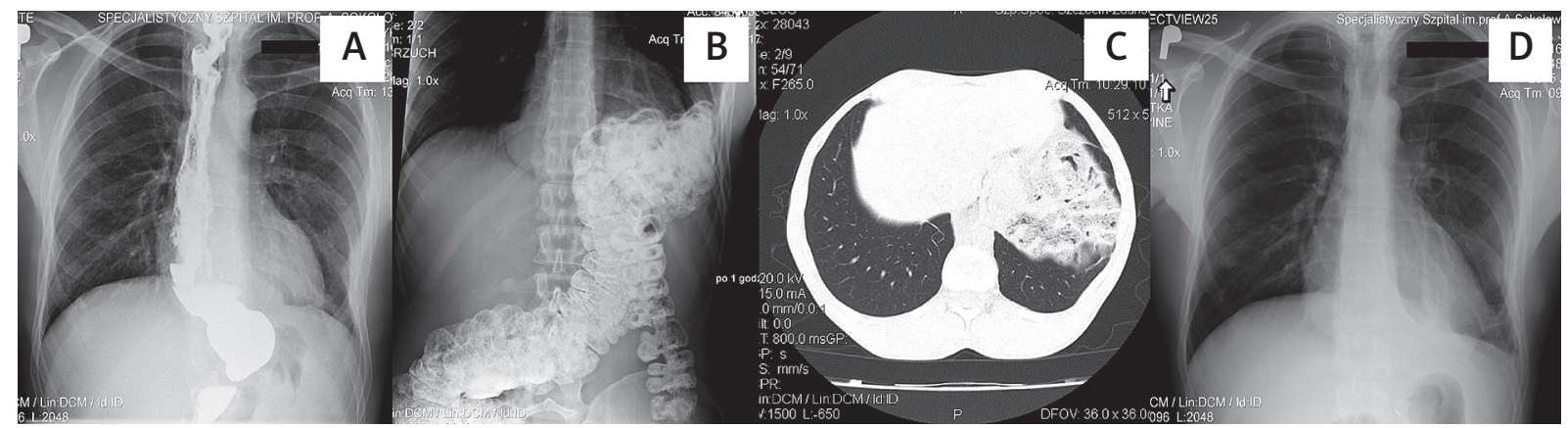

Fig. 2. A - Oral X-ray examination with contrast, performed on the $7^{\text {th }}$ postoperative day - normal view. B - Displacement of the colon into the mediastinum and left pleural cavity 12 months after the operation. The passage of the digestive tract. C - Horizontal computed tomography (CT) image: the colon protruding into the mediastinum and left pleural cavity. D - Final chest X-ray examination showing complete restoration

middle and the lower thirds of the esophagus. Subtotal minimally invasive esophagectomy (laparoscopy with VATS and cervicotomy) and two-field lymphadenectomy were performed. Stage IB (PT2NOMO) was confirmed by postoperative specimen evaluation. The postoperative course was uneventful. The patient complained of chest pain 1 year after the surgery. The symptom occurred in the supine position and resolved upon standing. Compression of the stomach graft by the colon protruding into the mediastinum through the esophageal hiatus was confirmed with computed tomography (Figs. 2 A-D). A decision was made to perform a reoperation using a laparotomy approach; the displaced colon was repositioned, plasty of the hiatus was performed, and the colonic mesentery was stabilized. The postoperative course was uneventful.

\section{Discussion}

By 2011, 82 cases of postesophagectomy hiatal hernia had been described in the literature [1]. Reports of 108 postoperative hiatal hernias, including the cases described by the present authors, have been found in the database so far [3, 4, 6-10]. The colon, small intestine, omentum, and even spleen can be found in postoperative hiatal hernias [1, $5,6,8,10]$. The most dramatic cases involving strangulation followed by ischemia of the colon or small intestine required additional resection $[1,5,7,10]$. This situation took place in the first reported case. The risk factors for the development of hiatal hernia include intraperitoneal pressure exceeding thoracic pressure and distension of the esophageal hiatus $[1,4,5,7,10]$. Postoperative hiatal hernias occur more often after minimally invasive (2.7-26\%) or robotic (up to $19.4 \%$ ) esophagectomy than after conventional procedures because of the surgical technique $[1,3,6,7,9]$. In both presented cases, the displaced organ was the transverse colon. In our opinion, the transverse colon is more susceptible to displacement when freed during the skeletonization of the greater gastric curvature, Kocher's maneuver, and potential omentectomy than intestinal loops stabilized by microjejunostomy. Intraoperative plasty of the esophageal hiatus or mesh implantation is recommended in order to prevent postesophagectomy hiatal hernia $[4,5,7]$. The clinical courses of the complications presented herein were different. Moreover, the two cases differed with regard to the technical details of the operations, making it difficult to determine the main cause of colonic displacement. The most likely reason seemed to be the relatively long mesentery of the colon and the associated joint traction of the graft and the colonic mesentery into the mediastinum. The treatment of choice in such cases is surgical intervention. The abdominal approach is preferred, with a growing frequency of laparoscopy $[1,3,5,6,9]$. In the event of technical difficulties, additional thoracic access or even typical posterolateral thoracotomy may be required [8].

\section{Disclosure}

Authors report no conflict of interest.

\section{References}

1. Price TN, Allen MS, Nichols FC, Cassivi SD, Wigle DA, Shen KR, Deschamps C. Hiatal hernia after esophagectomy: analysis of 2,182 esophagectomies from a single institution. Ann Thorac Surg 2011; 92: 2041-2045.

2. Schubert D, Dalicho S, Flohr L, Benedix F, Lippert H. Management of postoperative complications following esophagectomy. Chirurg 2012; 83: 712-718.

3. Lowe C, Subar D, Hall C, Kumpavat J, Decadt B, Agwunobi A. Hiatal hernias presenting as a late complication of laparoscopic-assisted cardio-oesophagectomy. Hernia 2010; 14: 211-213.

4. van Sandick JW, Knegjens JL, van Lanschot JJ, Obertop H. Diaphragmatic herniation following oesophagectomy. Br J Surg 1999; 86: 109-112.

5. Audebert A, Wind P, Sauvanet A, Douard R, Benichou J, Cugnenc PH, Belghiti J. Diaphragmatic hernia in a rare complication of oesophagectomy for cancer. Ann Chir 2005; 130: 21-25.

6. Willer BL, Worrell SG, Fitzgibbons RJ Jr, Mittal SK. Incidence of diaphragmatic hernias following minimally invasive versus open transthoracic Ivor Lewis McKeown esophagectomy. Hernia 2012; 16: 185-190.

7. Sutherland J, Banerji N, Morphew J, Johnson E, Dunn D. Postoperative incidence of incarcerated hiatal hernia and its prevention after robotic transhiatal esophagectomy. Surg Endosc 2011; 25: 1526-1530.

8. Royo Crespo I, Gil ER, Lostao EL, Benito MP. Bilateral herniation of the small intestine through the oesophageal hiatus. Eur J Cardiothorac Surg 2010; 37: 960

9. Bronson NW, Luna RA, Hunter JG, Dolan JP. The incidence of hiatal hernia after minimally invasive esophagectomy. J Gastrointest Surg 2014; 18: 889 893.

10. Vallböhmer D, Hölscher AH, Herbold T, Gutschow C, Schröder W. Diaphragmatic hernia after conventional or laparoscopic-assisted transthoracic esophagectomy. Ann Thorac Surg 2007; 84: 1847-1852. 